\title{
More Lessons Learned from the Holocaust - Towards a Complexity-Embracing Approach to Why Genocide Occurs
}

Timothy Williams

Centre for Conflict Studies, University of Marburg

Follow this and additional works at: https://digitalcommons.usf.edu/gsp

\section{Recommended Citation}

Williams, Timothy (2016) "More Lessons Learned from the Holocaust - Towards a Complexity-Embracing Approach to Why Genocide Occurs," Genocide Studies and Prevention: An International Journal: Vol. 9: Iss. 3: 137-153.

DOI:

http://dx.doi.org/10.5038/1911-9933.9.3.1306

Available at: https://digitalcommons.usf.edu/gsp/vol9/iss3/11

This Articles is brought to you for free and open access by the Open Access Journals at Digital Commons @ University of South Florida. It has been accepted for inclusion in Genocide Studies and Prevention: An International Journal by an authorized editor of Digital Commons @ University of South Florida. For more information, please contact digitalcommons@usf.edu. 


\section{More Lessons Learned from the Holocaust - Towards a Complexity-Embracing Approach to Why Genocide Occurs}

\section{Acknowledgements}

Acknowledgments: I would like to thank Paul Steinheuer, Alice Williams, Judith von Heusinger, Sergio Gemperle, Dominic Pfeiffer, Lisa Gutenbrunner and Kerstin Hamman for comments on early drafts of this work. 


\title{
More Lessons Learned From the Holocaust-Towards a Complexity-Embracing Approach to Why Genocide Occurs
}

\author{
Timothy Williams \\ Centre for Conflict Studies, University of Marburg \\ Marburg, Germany
}

\begin{abstract}
Why do genocides occur? This paper applies qualitative comparative analysis (QCA) to revisit this question, and analyses 139 cases of genocide and non-genocide. The paper demonstrates the importance of both priming, contextual conditions which provide a political opportunity structure conducive to genocide, as well as triggering, more proximate conditions which constitute immanent motivations. Most centrally, sufficiency is demonstrated for genocide occurrence when an autocratic regime and the salience of an elite's ethnicity are present, and are combined with either an exclusionary ideology or political upheaval. As such, the autocratic nature of the state provides an opportunity structure allowing genocide to occur, while the salience of elite ethnicity can serve as a motivation. Finally, the ideology and the political upheaval serve as an additional motivation or opportunity structure, respectively. While political upheaval can play a part in causing genocide, its role is much more understated than is suggested in previous literature.
\end{abstract}

Keywords: genocide, QCA, conflict processes

\section{Introduction}

Why genocides occur has been one of the central debates within the study of genocide over previous decades and has been informed by studies from a range of disciplines. It is an important research endeavour as it is pivotal to identify the conditions under which genocide occurs if there is ever to be any possibility of preventing genocide from occurring. In an attempt to shed fresh light on the debate this paper conducts a Qualitative Comparative Analysis (QCA) of the 40 genocide cases and 100 non-genocidal incidents which occurred between 1955 and 1998. The data used here builds on data from the Political Instability Task Force's State Failure Problem Set as is common in much of the emerging quantitative genocide literature and in Barbara Harff's seminal statistical paper "No Lessons Learned from the Holocaust? Assessing Risks of Genocide and Political Mass Murder since 1955."1 While drawing on the same dataset as several papers before, this paper takes the dataset further and interrogates the cases from a new methodological perspective, QCA. With this alternative method which is based on set-theory it is possible to tease out deeper insights from the data and allow for a richer analysis of why genocides occur.

Specifically, QCA provides a method for capturing the general patterns of genocide occurrence while also allowing for complexity better than other methods used hitherto, constituting a significant step forward in the understanding of the causes of genocides. Although genocide is a complex phenomenon, this paper suggests ways of breaking down central conditions which coalesce across certain subsets of categories by applying an alternative methodology thus far not used to address this question. This paper demonstrates that QCA - which is neither traditionally qualitative nor quantitative - is a suitable and possibly preferential methodology for studying genocide occurrence as it uses Boolean algebra to identify multiple pathways to genocide with different combinations of conditions acting as causes of genocide in different cases. QCA systematically provides different profiles of condition combinations which provoke genocide outbreak, thereby identifying necessary

\footnotetext{
${ }^{1}$ Harff, Barbara. 2003. “No Lessons Learned from the Holocaust? Assessing Risks of Genocide and Political Mass Murder Since 1955." American Political Science Review Vol. 97, No. 1, 57-73. Other quantitative genocide literature based on PITF data includes Colaresi, Michael and Sabine C. Carey. 2008. "To Kill or to Protect: Security Forces, Domestic Institutions, and Genocide." Journal of Conflict Resolution Vol. 52, No. 1, 39-67. Esteban, Joan, Massimo Morelli, and Dominic Rohner. Forthcoming. "Strategic Mass Killings." Journal of Political Economy. Goldsmith, Benjamin E., Charles R. Butcher, Dimitri Semenovich, and Arcot Sowmya. 2014. "Forecasting the Onset of Genocide and Politicide. Annual out-of-sample forecasts on a global dataset, 1988-2003." Journal of Peace Research Vol. 50, No. 4, 437-452. Krain, Matthew. 1997. "State-Sponsored Mass Murder: The Onset and Severity of Genocides and Politicides." The Journal of Conflict Resolution Vol. 41, No. 3, 331360. Montalvo, Jose G. and Marta Reynal-Querol. 2008. "Discrete Polarisation with an Application to the Determinants of Genocides." The Economic Journal Vol. 118, No. 9, 1835-1865. Rost, Nicolas. 2013. "Will It Happen Again? On the possibility of forecasting the risk of genocide." Journal of Genocide Research Vol. 15, No. 1, 41-67. Ulfelder, Jay and Benjamin Valentino. 2008. "Assessing Risks of State-Sponsored Mass Killing." Working Paper.
}

Timothy Williams, "More Lessons Learned From the Holocaust-Towards a Complexity-Embracing Approach to Why Genocide Occurs" Genocide Studies and Prevention 9, 3 (2016): 137-153. @2016 Genocide Studies and Prevention. http://dx.doi.org/10.5038/1911-9933.9.3.1306 
and sufficient conditions. This paper demonstrates that sufficient and necessary causes can be found when examining genocides. The findings are less parsimonious than previous statistical results but offer a more realistic picture of the complex conditions that can be seen as sufficient or necessary for genocide to occur. This research, thus, has the potential of providing a framework for policy makers and civil society actors for anticipating when genocidal situations are more likely to arise, providing configurations of conditions of when genocide has occurred in the past.

This paper will first clarify some issues around the concept of genocide, before presenting a theoretical framework of different determinants emphasised in previous research and explaining the merits of the chosen QCA approach. Subsequently, the case and condition choice will be explained in detail, as well as their respective operationalisations. Finally, the results of the QCA will be presented and expanded in an empirical analysis, before bringing together these results to identify the central determinants of genocide and demonstrate how these results are a step forward for the study of genocide occurrence.

\section{Why Do Genocides Occur?}

This section will discuss various conditions identified previously as central to causing genocide occurrence. It is helpful to split them into two types of categories: priming, contextual conditions and motivating, triggering conditions. The first priming conditions provide a context which is opportune for genocide, and suggest conditions can help to overcome certain societal or international restrictions; these conditions should as such not suffice to cause genocide, but instead they necessitate a triggering conditions, something about why key actors want genocide to occur and thus instigate it. In the following discussion of various conditions, the presence of an autocratic regime and an economically autarkic economy can be seen as setting the context, while an exclusionary ideology has a more triggering character; other conditions could play into both categories to varying degrees. It is to be expected that any situation of genocide arises out of a context conducive to it, combined with triggering motivations. Thus, the QCA solutions are expected to combine several of the following conditions to create individually sufficient pathways to genocide. Genocide is taken here to mean "the promotion, execution, and/or implied consent of sustained policies by governing elites or their agents - or, in the case of civil war, either of the contending authorities - that are intended to destroy, in whole or part, a communal, political, or politicized ethnic group." 2 This definition of genocides and politicides is the foundation of Harff's comprehensive list of genocides and politicides which underlies the dataset used in this paper.

\section{Political Upheaval}

The most commonly cited determinant of genocide occurrence, in both qualitative and quantitative studies, is political upheaval and direct threats to governments which also finds a prominent position in Harff's study.3 Harff defines political upheaval as "an abrupt change in the political community caused by the formation of a state or regime through violent conflict, redrawing of state boundaries, or defeat in international war." 4 In this context, Melson and Krain emphasise the importance of revolutions, ${ }^{5}$ but it is also a category in which decolonisation or other radical system changes or collapses would equally be well placed. The logic behind all these is that political upheaval provides a context and a political opportunity structure which is conducive to starting genocide. With the constraints of a previous system removed, the legitimacy of the political community and

\footnotetext{
${ }^{2}$ Harff, "No Lessons Learned ", 58.

${ }^{3}$ Chalk, Frank and Kurt Jonassohn. 1990. The History and Sociology of Genocide: Analyses and Case Studies. New Haven: Yale University Press. Harff, "No Lessons Learned". Krain, "State-Sponsored Mass Murder". Goldsmith et al. "Forecasting the Onset of Genocide and Politicide". Melson, Robert. 1992. Revolution and Genocide. On the Origins of the Armenian Genocide and the Holocaust. Chicago: University of Chicago Press. Rost, 'Will It Happen Again?'. Rummel, Rudolph. 1994. Death By Government. New Brunswick: Transaction Publishers. Weitz, Eric D. 2003. "The Modernity of Genocides; War, Race, and Revolution in the Twentieth Century." in The Specter of Genocide: Mass Murder in Historical Perspective. Edited by Robert Gellately and Ben Kiernan, 53-74. Cambridge: Cambridge University Press.

${ }^{4}$ Harff, "No Lessons Learned ", 62.

${ }^{5}$ Melson, Revolution and Genocide. Krain, "State-sponsored mass murder".
} 
its identity (including which groups constitute it) can be called into question. ${ }^{6}$ Political upheaval provides the opportunity to re-define the demos, the circle of people included as constituents of the state, in a deinstitutionalised setting. ${ }^{7}$ In the context of political upheaval, rules of conduct between the state and its population can become re-defined and enable a regime intent on genocide to implement a new eliminationist policy. The period of transition, and the often concurrent chaos, can also serve as a smokescreen for action against the targeted group, given that internal and external observers could be distracted by other macro-political transformation processes. Besides providing a contextual background, political upheaval can also be a motivational impulse and thus trigger genocide. In the throes of political upheaval, reigning elites may feel particularly threatened by certain groups they believe could try to exploit the upheaval to topple them, and thus desire to have these groups removed. The empirical founding of the impact of political upheaval since World War II is immense and Harff finds a significant impact on the risk of genocide occurrence, while Krain suggests that extra-constitutional changes (a similar concept) have a significant impact on this likelihood. ${ }^{8}$

War

A further condition often associated with genocide occurrence is war, ${ }^{9}$ and for Krain a country's involvement in civil war is the single most significant determinant of genocide occurrence in his statistical study. ${ }^{10}$ War is here defined as "a contested incompatibility that concerns government and/or territory where the use of armed force between two parties, of which at least one is the government of a state, results in at least 25 battle-related deaths." ${ }^{11}$ War can be seen as a contextual condition which - as suggested above for political upheaval - provides a conducive opportunity structure for genocides to emerge: war allows the destruction of a population to happen as other policy options are closed off or the state becomes increasingly autonomous from other internal social forces, such as public opinion. ${ }^{12}$ Moreover, war provides the opportunity to scapegoat certain unwanted groups and portray them as internal enemies of the state who are coalescing with the external enemies one is fighting militarily in the war, triggering a genocide against them. Also, in particular in the context of guerrilla wars, wars can motivate governments to include genocide in military strategy as rebels are particularly dependent on their local populations for support and security. ${ }^{13}$

Both political upheaval and war thus encompass a political opportunity structure founded on an exceptional situation which removes the standard constraints of government from the political elites. However, there are two key differences between war and political upheaval in the mechanics of how they affect genocide occurrence. First, political upheaval can be nonviolent, while war inherently brings with it the internal mobilisation of arms, minimally through the secondment of military troops, oftentimes also in the armament of civilian defence groups, paramilitaries or similar groups. This expansion of available weapons and their distribution to wider circles of the population make it possible to then implement a genocidal policy quickly and effectively, particularly if these civilian or paramilitary groups are encompassed in a strong military or other hierarchy of authority; furthermore, such armament and genocidal operations can go largely unnoticed in the more general context of military war action. Second, war - both civil and international - tends to strengthen the political elites' hold on power (in the areas under their control) as security fears in the population can increase popular support and facilitate rallying

\footnotetext{
${ }^{6}$ Melson, Revolution and Genocide, 21.

${ }^{7}$ Mann, Michael. 2005. The Dark Side of Democracy: Explaining Ethnic Cleansing. Cambridge: Cambridge University Press.

${ }^{8}$ Harff, “No Lessons Learned". Krain, "State-Sponsored Mass Murder".

${ }^{9}$ Melson, Revolution and Genocide. Rummel, Death By Government. Weitz, "Modernity".

${ }^{10}$ Krain, "State-Sponsored Mass Murder".

${ }^{11}$ Gleditsch, Nils Petter, Peter Wallensteen, Mikael Eriksson, Margareta Sollenberg, and Håvard Strand. 2002. "Armed

Conflict 1946-2001: A New Dataset." Journal of Peace Research Vol. 39, No. 5, 615-637.

${ }^{12}$ Melson, Revolution and Genocide, 19.

${ }^{13}$ Valentino, Benjamin, Paul Huth, and Dylan Balch-Lindsay. 2004. “'Draining the Sea': Mass Killing and Guerrilla Warfare." International Organization Vol. 58, No. 2, 375-407.
} 
around the leadership in order to avert a military defeat; further, war is normally fought between two or more clearly demarcated parties, while political upheaval can include struggles for power between unclear and diffuse constellations of actors. Both these aspects differ fundamentally from political upheaval in which the political elites wanting to pursue genocide capitalise on political uncertainty and destabilisation.

\section{Elite Ethnicity and Ethnic Cleavages}

Defined as "states with re-existing internal cleavages and real opposition,"14 pluralistic states have often come into existence during the process of colonisation and decolonisation when multiethnic states emerged as borders were determined arbitrarily by colonial masters. ${ }^{15}$ While ethnic fractionalization measures the actual degree of these internal cleavages, much more significant is the actual impact this has and the perception of these cleavages within the societies themselves. Thus, Harff suggests the incorporation of the ethnic character of the ruling elite, i.e. whether the ethnicity of the ruling elites is salient. The concept used here does not differentiate between whether the political leadership comes from a minority or a majority ethnic group but solely asks whether its ethnicity is important.

The causal logic underlining this condition is that if elites are disproportionately from one section of society and this power differential based on ethnicity is perceived as such and regarded as salient in the population, underrepresented groups may challenge this. These challenges to the elites' political power could prompt them to frame security and ideology in communal terms, e.g. advocating racial denigration or exclusion of the other groups. These ethnic factors, as argued here, could participate in causing genocide in conjunction with other conditions, such as political upheaval (as this creates a situation of uncertainty in which elites have incentives to mobilise along ethnic lines). Given the broad definition of genocide beyond just ethnic groups, it cannot be expected that the salience of elite ethnicity will be a determining feature for all genocides, but when present it will be able to help explain mechanisms for victim group identification and, to a certain degree, elite motivation.

A further condition that is sometimes mentioned is political and economic discrimination of a minority. However, such discrimination can lead to this group's political mobilisation and, in turn, to repression by the state. This repression can escalate into genocide. However, this is only an intervening condition and the discrimination will stem from other sources, such as disproportionate elite representation or an exclusionary ideology. Since political and economic discrimination of a group could only be an indicative warning sign of genocide, rather than the actual reason for genocide happening, it will not be included as a condition here. The decision to include only the salience of elite ethnicity is a pragmatic choice for the application of $Q C A,{ }^{16}$ but it is also theoretically more interesting to include this than discrimination as a condition in the analysis.

\section{Autocratic Regime}

Rummel adapted Lord Acton's iconic phrase on corruption to read "Power kills; absolute power kills absolutely."17 In countries with limited and accountable power, democides (as he terms mass murder by governments of their own citizens) are less likely to happen because of cross pressures and the associated political culture. This argument can be focused on a more narrow definition of democracies, in which no one group can become the driving force and there is a democratic culture which "involves debate, demonstration, and protests as well as negotiation, compromise, and tolerance." 18 Inversely, autocratic regimes have a free hand at dealing with

\footnotetext{
${ }^{14}$ Fein, Helen. 1990. "Genocide: A Sociological Perspective." Current Sociology Vol. 38, No. 1,39.

${ }^{15}$ Kuper, Leo. 1981. Genocide. Its Political Use in the Twentieth Century. New Haven: Yale University Press.

${ }^{16}$ This is due to the fact that the number of truth table lines expands exponentially to the number of conditions included, so that it is unwise to include too many conditions in any one analysis. Thus, it would not be fruitful to include two conditions which are so similar.

${ }^{17}$ Rummel, Death By Government.

${ }^{18}$ Rummel, Death By Government, 23.
} 
disagreeable groups with no other actors constraining their actions or contesting one-sided genocidal action, clearly demarcating this as an opportunity condition. This is reinforced by Colaresi and Carey's findings in their statistical analysis that genocide occurrence is conditional on "institutional executive constraints". ${ }^{19}$ While Harff finds autocracies to be three-and-a-half times more likely to commit genocide than democracies, Krain finds no statistical relation. ${ }^{20}$ However, one can expect that it will play a role particularly in cases in which an exclusionary ideology is perpetuated by the elites, who then have free hand to act on their ideology, or in cases of political upheaval, as the autocratic elites must fear losing power and thus attempt to consolidate their position by drastically changing the playing field, as was evidenced by Hutu radicals in the 1994 Rwanda genocide.

\section{Exclusionary ideology}

Chalk and Jonassohn posit that modern genocide is implemented as an ideology, selecting victims according to who they are, not what they have or where they are, as in premodern genocides. ${ }^{21}$ Harff also emphasises the importance of exclusionary ideologies and finds that they significantly impact the probability of genocide occurrence. She defines an exclusionary ideology as "a belief system that identifies some overriding purpose or principle that justifies efforts to restrict, persecute, or eliminate certain categories of people." ${ }^{22}$ Freeman posited that while neither a strong state nor a pluralistic society were strictly necessary for genocide occurrence a genocidal ideology is. ${ }^{23}$ It does not seem apparent that such an ideology should be necessary for genocide occurrence, as there are several examples of cases in which genocide is a rational, political decision, rather than an ideological impulse. However, an elite that subscribes to an exclusionary ideology, and has the capacity to follow through, needs no other conditions for genocide to occur, making this a motivational condition. For instance, Mann demonstrates that the most important genocidal ideology in modernity has been that of the unified nation-state, from which the victim group is excluded. ${ }^{24}$ Exclusion becomes possible because in the process of building a new nation, a new identity can be created which redefines the demos (citizens of the state) to include only one ethnos (ethnic sub-group in the country), thus expelling the victim group from the security of citizenship and opening up the possibility of their destruction. This condition should not be conflated with the salience of elite ethnicity, as an exclusionary ideology can but does not need to be congruent with ethnic categorisations. For instance, in the context of a politicide, the exclusionary ideology can be directed also at groups which are politically, economically or socially defined, such as the urban population or intellectuals under the Khmer Rouge regime.

\section{Economic and Political Autarky}

A further contextual, opportunity condition not commonly mentioned in the genocide literature, which nonetheless played an important part in Harff's analysis, is a country's degree of international involvement and interdependence, particularly regarding how strong political and economic ties and dependencies are..$^{25}$ Similarly to a democratic setting, this interdependence constrains elites' actions. The more interdependent a country is, the less likely it is to choose genocide as a course of action due to the possibility of facing hard repercussions from international reactions. On the other hand, there are two consequences for politically or economically relatively isolated (autarkic) states. Leaders of such states can, firstly, work on the assumption that they can act without having to fear too strong economic repercussions as their economies or political systems are for the most part dependent only on internal dynamics. For instance, countries with relatively independent

\footnotetext{
${ }^{19}$ Colaresi and Carey, "To Kill or to Protect".

${ }^{20}$ Harff, “No Lessons Learned". Krain, "State-Sponsored Mass Murder".

${ }^{21}$ Chalk and Jonassohn, History and Sociology.

${ }^{22}$ Harff, “No Lessons Learned", 63.

${ }^{23}$ Freeman, Michael. 1991. "The Theory and Prevention of Genocide." Holocaust and Genocide Studies Vol. 6, No. 2, 185-199.

${ }^{24}$ Mann, Dark Side of Democracy.

${ }^{25}$ Harff, “No Lessons Learned".
} 
economies will have less to fear from economic boycotts. Secondly, these state leaders can also assume that the occurrences within their borders will be less interesting and important for more powerful states, as they have few interests to protect here, and thus will be less likely to intervene in any genocidal action. In Harff's analysis, political interdependence has no significant impact, while economic interdependence does; following Harff's findings this analysis will include only economic interdependence.

\section{Case Selection and Conditions Operationalisation}

The QCA model for this paper takes as its unit of analysis events of political instability identified in the Political Instability Task Force's (PITF) State Failure Problem Set between 1955 and 1998, as is common in most recent contributions to quantitative genocide studies. ${ }^{26}$ The analysis focusses on occurrence of genocide as the dependent outcome (coded one for occurrence and zero for non-occurrence) and six key independent conditions. All values of independent conditions and dependent outcome must be coded dichotomously for all cases-is this condition present or absent in each case? Unless otherwise specified the values of these conditions are selected from the first year of the genocide or non-genocidal conflict (or as close as possible when data points are missing), in order to avoid reverse causality by which the genocide or non-genocide itself would impact these conditions which are supposed to be determining its outbreak. Table 1 shows the number of cases (genocidal and non-genocidal) per condition.

Genocide. As genocide definitions vary, the lists of included cases in different studies diverge also. Most of the recent quantitative literature builds on the Political Instability Task Force's (PITF) State Failure Problem Set, which in its updated form includes genocides and non-genocides from 1955 until $2006^{27}$ and this is also the basis for Harff's list and analysis. ${ }^{28}$ In order to ensure full comparability to the non-genocides regarding time frame, this paper focuses on genocides which began between 1955 and 1998, thus excluding only one of Harff's cases (Sudan since 2003), and resulting in altogether 40 cases of genocide in this study. Non-genocides are taken as any other case in the PITF consolidated list, encompassing 99 events coded as adverse regime changes, ethnic wars or revolutions, but which are not coded as genocide; the logic underlying this choice of nongenocides is that political instability or upheaval is posited widely to be a precursor for genocide. Therefore, as in Harff's study, the non-genocides included in this paper are interesting as they are cases of political upheaval which have not developed into genocide. This is possibly not the optimal operationalisation of the concept of non-genocides as potential genocides which did not happen, but in order to ensure the comparability of this study to Harff's seminal work and with the theoretical foundation of instability breeding genocide, it would seem a plausible strategy. Nonetheless, it will still be an important part of this paper to analyse the importance of political upheaval in determining genocide occurrence. However, rather than looking into the mere presence of political upheaval, it will look at the magnitude of political upheaval present in a country, thus avoiding any interaction between the condition of political upheaval and the outcome genocide or non-genocide.

\footnotetext{
${ }^{26}$ Colaresi and Carey, "To Kill or to Protect". Esteban et al., "Strategic Mass Killings". Goldsmith et al. "Forecasting the onset of genocide and politicide". Harff, "No Lessons Learned". Krain, "State-Sponsored Mass Murder". Montalvo and Reynal-Querol, "Discrete Polarisation with an Application to the Determinants of Genocides". Rost, "Will it happen again?". Ulfelder and Valentino, "Assessing Risks of State-Sponsored Mass Killing".

${ }^{27}$ Operational guidelines applied by Harff, "No Lessons Learned", page 58 in compiling this list are: 1. Complicity of the state or contending authorities; 2 . Evidence of intent; 3 . Victims as members of an identifiable group; 4 . Policies and practices that cause prolonged mass suffering; 5 . Threat posed to survival of the group by these actions. These guidelines produce the following list of cases of genocide: Afghanistan 1978-92, Algeria 1962, Angola 1998-2002, Angola 1975-94, Argentina 1976-80, Bosnia 1992-95, Burundi 1993, Burundi 1988, Burundi 1965-73, Cambodia 1975-79, Chile 1973-76, China 1959, China 1966-75, DR Congo 1964-65, DR Congo 1977-79, El Salvador 1980-89, Equatorial Guinea 1969-79, Ethiopia 1976-79, Guatemala 1978-90, Indonesia 1965-66, Indonesia 1975-92, Iran 1981-92, Iraq 1988-91, Iraq 1963-75, Myanmar (Burma) 1978, Nigeria 1967-70, Pakistan 1973-77, Pakistan (now Bangladesh) 1971, Philippines 1972-76, Rwanda 1994, Rwanda 1963-64, Somalia 1988-91, Sri Lanka 1989-90, Sudan 2003-ongoing, Sudan 1983-2002, Sudan 1956-72, Syria 1981-82, Uganda 1971-79, Uganda 1980-86, Vietnam South 1965-75, Yugoslavia 1998-99.

${ }^{28}$ Harff, Barbara. "Annual Data on cases of Genocides and Politicides 1955-2006.xls." Available from http://www.gpanet. org/content/genocides-and-politicides-events-1955-2002. (accessed 12 November 2012).
} 
Table 1: Overview of condition distribution.

\begin{tabular}{|c|c|c|c|c|}
\hline & & $\begin{array}{c}\text { Genocides } \\
(40)\end{array}$ & $\begin{array}{l}\text { Non-genocides } \\
\text { (99) }\end{array}$ & $\begin{array}{l}\text { Total } \\
(139)\end{array}$ \\
\hline $\begin{array}{l}\text { Autocracy } \\
\text { (A) }\end{array}$ & $\begin{array}{l}\text { Absence of } \\
\text { democratic controls } \\
\text { to constrain the } \\
\text { government }\end{array}$ & 38 (95\%) & $69(69 \%)$ & 107 (77\%) \\
\hline $\begin{array}{l}\text { Political Upheaval } \\
\text { (P) }\end{array}$ & $\begin{array}{l}\text { Abrupt change } \\
\text { to the power } \\
\text { constellations in the } \\
\text { political community }\end{array}$ & $25(62.5 \%)$ & 31 (31\%) & $56(40 \%)$ \\
\hline $\begin{array}{l}\text { War } \\
(\mathrm{W})\end{array}$ & $\begin{array}{l}\text { Use of armed } \\
\text { force between two } \\
\text { parties, including } \\
\text { a country's } \\
\text { government }\end{array}$ & $26(65 \%)$ & 54 (54\%) & $80(58 \%)$ \\
\hline $\begin{array}{l}\text { Exclusionary Ideology } \\
\text { (I) }\end{array}$ & $\begin{array}{l}\text { Belief system with } \\
\text { an overriding } \\
\text { principle that } \\
\text { justifies efforts to } \\
\text { restrict, persecute, } \\
\text { or eliminate victim } \\
\text { group }\end{array}$ & $25(62.5 \%)$ & $22(22 \%)$ & 47 (34\%) \\
\hline $\begin{array}{l}\text { Salience of Elite } \\
\text { Ethnicity } \\
\text { (S) }\end{array}$ & $\begin{array}{l}\text { Importance of the } \\
\text { elite's ethnicity for } \\
\text { the country's politics }\end{array}$ & 32 (80\%) & $45(45 \%)$ & 77 (55\%) \\
\hline $\begin{array}{l}\text { Economic Autarky } \\
\text { (E) }\end{array}$ & $\begin{array}{l}\text { Absence of strong } \\
\text { economic ties to } \\
\text { other countries }\end{array}$ & $18(45 \%)$ & $22(22 \%)$ & $41(29 \%)$ \\
\hline
\end{tabular}

Autocratic regime (A). This indicator of whether a regime is autocratic (1) or non-autocratic (0) is taken from the Polity IV dataset variable POLITY ${ }^{29}$ and reassessed using Freedom House's Freedom in the World index. ${ }^{30}$ Altogether, there are 107 autocracies included in the study, along with 32 democracies; $95 \%$ of genocidal events occur in autocratic countries and $69 \%$ cases of nongenocides are also autocratic.

Political upheaval $(P)$. Given the focus on political upheaval in the definition of the outcome, the condition of interest here is not the presence or absence of political upheaval itself, butfollowing Harff-a differentiation between high levels and low levels of political upheaval. A case is classified as being in political upheaval $(\mathrm{P})$ if either the difference of the highest and lowest democracy / autocracy values over the whole conflict is 10 or higher (indicating a system

${ }^{29}$ Center for Systemic Peace, Polity IV Annual Time-Series 1800-2011, Polity IV Project, Political Regime Characteristics and Transitions, 1800-2011, 2011. Available from: http://www.systemicpeace.org/inscr/inscr.htm. (accessed 15 May 2013). For the precise coding procedure see Marshall, Monty G. Keith, Jaggers, and Ted Robert Gurr. 2011. "Dataset Users' Manual. Polity IV Project." Vienna, VA: Center for Systemic Peace. Available from: http://www.systemicpeace.org/inscr/ p4manualv2010.pdf. (accessed 01 March 2013), 15ff.

${ }^{30}$ Freedom House. 2013. “Country ratings and status, FIW 1973-2013.” Washington, DC: Freedom House. Available from: http://www.freedomhouse.org/report-types/freedom-world. (accessed 15 May 2013). 
change from either autocracy to democracy or vice versa), or if the maximum value of the political upheaval variable in Harff's dataset during the conflict is 30 or higher. ${ }^{31}$ Harff operationalises political upheaval using the "the sum of the maximum magnitude of events in the prior 15 years, including revolutionary wars, ethnic wars, and regime crises" from the State Failure Problem Set. ${ }^{32}$ Thus, the value 0 indicates that there were no such politically upheaving events in the 15 years prior to the genocide or non-genocide, while the value 60 indicates that each of the previous years had the highest upheaval magnitude of 4 . Any cases with a value of lower than 15 were classified as not having political upheaval while all intermediate cases (between 15 and 30) were classified after a qualitative assessment of the individual cases by the author; this qualitative assessment of intermediate cases ensures that the thresholds are not arbitrary. Altogether, there are 56 cases in which high political upheaval is present, which constitutes $40 \%$ of the dataset. As with autocracy, a significant difference is notable between genocides and non-genocides, with $62.5 \%$ of genocides having some degree of prior political upheaval, while this is only the case in $31 \%$ of non-genocides.

War $(W)$. Data on whether a country is at war was taken from the UCDP-Peace Research Institute, Oslo (PRIO) armed conflict dataset, ${ }^{33}$ classifying any case as at war (1) if it was labelled as such in the armed conflict dataset during any year of the case (80 cases $(58 \%)$, whereby $65 \%$ of genocidal events occur in the context of war, compared with $54 \%$ of non-genocidal events).

Exclusionary ideology (I). Harff codes exclusionary ideology herself as "belief systems that are articulated by governing elite, and that identify some kind of overriding purpose or principle that is used to restrict, persecute, or eliminate categories of people who are defined as antithetical to that purpose or principle." ${ }^{34}$ In cases in which there is no coding available from Harff, cases were coded by the author according to in-depth accounts of the cases. Hereby, 1 signals the presence of such exclusionary ideologies among the elites (47 cases). $62.5 \%$ of genocides have an exclusionary ideology present, in contrast to only $22 \%$ of non-genocides.

Salience of elite ethnicity (S). Regarding the salience of elite ethnicity the dataset differentiates between elite ethnicity not being salient (0) (62 cases) and ethnicity being salient whereby the political leadership is representative of a majority or minority communal group or coalition (1) (77 cases). In Harff's analysis, she divides the latter category into two; however, this differentiation is not needed here as there is no theoretically plausible reason for there to be a difference between majority and minority communal groups.

Economic autarky $(E)$. Data on the condition regarding economic interdependence and autarky was sourced from World Bank import and export data. These data were added together (as percentages of the country's gross domestic product in the relevant year) to indicate the trade openness of a country. Case were coded as economically autarkic (1) if their trade percentage was below the world average according to the World Bank data over the relevant time frame from 1960 until 1998, which was 33\% (41 cases), and otherwise as economically interdependent (0) (98 cases).

\section{QCA - an Intermediate Method for Multi-Causal Phenomena}

Qualitative Comparative Analysis (QCA) is first used here to study the subject of genocide occurrence. Popularised in the social sciences by Charles Ragin, ${ }^{35}$ this method categorises cases by combinations of conditions leading to the occurrence or non-occurrence of the outcome, and reduces these combinations to the lowest common denominator using Boolean algebra. By executing this reduction one can show which conditions are necessary and which are sufficient for

\footnotetext{
${ }^{31}$ Harff, Barbara. "Genocide and Politicide Model Data (Phase III: 1955-1999)." Available from: http://www.gpanet.org/ webfm send/51. (accessed 11 January 2013).

${ }^{32}$ Harff, "No Lessons Learned".

${ }^{33}$ Uppsala Conflict Data Program-Peace Research Institute Oslo. 2012. “UCDP/PRIO Armed Conflict Dataset v.4-2012, 1946 - 2011." Oslo: Peace Research Institute Oslo. Available from: http://www.pcr.uu.se/research/ucdp/datasets/ucdp prio armed conflict dataset. (accessed 15 May 2013).

${ }^{34}$ Harff, "Genocide and Politicide." Model Data. Harff, “No lessons learned”, 63.

${ }^{35}$ Ragin, Charles. 2008. Redesigning Social Inquiry. Fuzzy Sets and Beyond. Chicago: University of Chicago Press. Ragin, Charles. 1987. The Comparative Method. Berkeley: University of California Press.
} 
causing the outcome. The dependent outcome can be caused not by the same condition in all cases, but by different combinations of multiple conditions, each coming to a fore in different cases.

QCA is thus an intermediate method between quantitative and qualitative methodologies, as it traditionally relies on a strong qualitative judgement by the researcher when categorising the cases, but uses a mathematical technique to categorise and reduce complexity. Its key advantage is its ability to cope with multiple pathways to an outcome, each consisting of different combinations of conditions. QCA allows several conditions to act together in unison, following a conjunctural logic, and also allows for conditions to act differently in different cases depending on their interaction with other conditions. Another key strength, the importance of the qualitative input of the research when coding the conditions, is also its main weakness. As a set-theoretical method, it can only cope with dichotomous conditions, thus losing much information about the countries being studied and not sufficiently allowing for ambiguous cases to be coded appropriately, as they must fit the box. However, there are methodological developments towards fuzzy set QCA (fsQCA) which allows for a more continuous categorisation. However, fsQCA cannot work with a dichotomous outcome such as genocide occurrence, so this paper will remain with classic so-called crisp set QCA (csQCA), pointing out contentious categorisations. Thus, with this method, this paper hopes to go beyond Harff's original statistical analysis, ${ }^{36}$ pinpointing several key combinations that can lead to the occurrence of genocide. While QCA is classically used for medium-n datasets, its application to larger numbers of cases is not unprecedented and allows for a different perspective on the data than a statistical analysis would allow, better allowing for equifinality and complex, configurative causation. ${ }^{37}$

\section{Why do Genocides Occur? Empirical Results from the QCA}

To approach this data with QCA, each condition must first be specified for each of the cases. Purely by looking at this unsorted table, as well as Table 2 below, it is plain to see that autocratic regimes (A) are present in nearly all genocide cases (38 out of 40 , that is $95 \%$ of cases), approximating a perfect score as a necessary cause for the outcome of genocide occurrence. This goes against the argument that liberal democracies also perpetrate genocide, but for post-1945, physical genocides this result of most occurring in autocratic settings remains interesting. ${ }^{38}$ However, some cases of non-genocide also occur in autocracies - thus an autocracy is a necessary condition for genocide occurrence, but not sufficient. The truth table also provides further central conditions which are sufficient for genocide occurrence, i.e. that the presence of this combination will always lead to the outcome, although not all instances of the outcome will be caused by this combination.

This analysis of sufficient conditions is the cornerstone of QCA and requires the re-categorisation of this information into a so-called truth table in which each logical combination of independent conditions constitutes one row. This study has six conditions (A, P, W, I, S, E) ) $^{39}$ leading to the outcome genocide, meaning that there will be $64\left(2^{6}\right)$ rows of possible combinations in the truth table. A row could read $\mathrm{A}^{*} \mathrm{P}^{*} \mathrm{~W}^{*} \mathrm{I}^{*} \mathrm{~S}^{*} \mathrm{E}$ (as in the case of Rwanda 1994), and $\mathrm{A}^{*} \mathrm{P}^{*} \mathrm{~W}^{*} \sim \mathrm{I}^{*} \mathrm{~S}^{*} \mathrm{E}$ (as in the case of Bosnia 1992-95). ${ }^{40}$ The truth table then assigns to these combinations the presence or absence of the outcome; in these two cases, it is present. By combining the two terms, one can say that I is irrelevant for the outcome genocide in the presence of all other five conditions, as I is present in one

\footnotetext{
${ }^{36}$ Harff, "No Lessons Learned".

${ }^{37}$ Bara, Corinne. 2014. "Incentives and Opportunities: A Complexity-Oriented Explanation of Violent Ethnic Conflict." Journal of Peace Research Vol. 51, No. 6, 696-710.

${ }^{38}$ It should be noted that there is a broad literature which also discusses the occurrence of genocide in liberal democracies, particularly in a settler colonial context, however given the nature of the dataset as a post-1945 timeframe and its focus on physical violence, genocide appears to happen nearly exclusively in autocratic countries. See for a discussion of liberal democratic genocides Moses, A. Dirk. 2002. "Conceptual Blockages and Definitional Dilemmas in the 'Racial Century': Genocides of Indigenous Peoples and the Holocaust." Patterns of Prejudice Vol. 36, No. 4, 7-36. Powell, Christopher. 2007. “What Do Genocides Kill? A Relational Conception of Genocide." Journal of Genocide Research Vol. 9, No. 4, 527-547.

${ }^{39}$ Generally, capital letters signal the presence of a condition, while the symbol before the letter denotes the condition's absence.

${ }^{40}$ The asterisk * is to be read as a 'logical and', meaning that all these conditions must happen together for the effect to occur.
} 
Table 2: Autocracy as quasi-necessary for genocide.

\begin{tabular}{|l|c|c|}
\hline & Autocracy absent & Autocracy present \\
\hline Genocide & 2 cases (5\%) & 38 cases $(95 \%)$ \\
\hline No genocide & 30 cases $(30 \%)$ & 69 cases $(69 \%)$ \\
\hline
\end{tabular}

case and absent in another. By continually combining truth table rows in this manner, it is possible to reduce the whole table to a selection of solution sets. ${ }^{41}$

As the amount of combinations rises exponentially by the number of conditions included, the six conditions included here produce a relatively intricate solution. When the data is reduced according to the principles of Boolean algebra, there are several possible ways for the condition combinations to be reduced, complex, intermediate and parsimonious solutions. ${ }^{42}$ Here an intermediate solution has been chosen, but the complex and parsimonious solutions are reported in the appendix. It is normally standard practice to select an intermediate solution, so that as many genocides as possible are covered by the solution, without including too many non-genocides as well; also, in this case the complex and parsimonious solutions lose out strongly regarding coverage and consistency values, ${ }^{43}$ respectively, vis-à-vis the intermediate solution; further, with five configurations the intermediate reduction allows for a more meaningful interpretation of the solution. Using this intermediate solution one receives the following formula:

\section{Solution: \\ $A^{*} S^{*} I+A^{*} S^{*} P+A^{*} I^{*} E^{*} P^{*} \sim W+A^{*} I^{*} E^{*} \sim P^{*} W+S^{*} \sim I^{*} E^{*} P^{*} W$}

These five terms altogether can explain a significant amount of variance between genocide and non-genocide. First, technical features of this solution will be discussed and then what it means substantively for the research question of why genocides occur.

Table 3 lists coverage and consistency scores for this solution. The coverage score of 0.750 indicates that altogether this solution can explain $75 \%$ of genocide cases, that is 30 out of 40 genocide occurrences, leaving only one quarter of the cases of genocide unexplained. Nonetheless, the consistency is not perfect and with these combinatory solutions, some non-genocides are also predicted to be genocides: $76.9 \%$ of the cases with these condition combinations are actually genocides, whereas only $23.1 \%$ are non-genocide, so-called false positives. Altogether 39 cases were predicted as genocide, of which 30 were actually genocides, and 9 were non-genocides,

\footnotetext{
${ }^{41}$ In most rows it is clear whether to code the outcome as genocide or not when there are multiple cases, but in some rows there are cases with diverging outcomes meaning that the researcher must decide whether to include the rows as present, absent or ambiguous. Ambiguous cases (or 'Don't care' in QCA terms and represented by a dash (-) mean that this particular combination of conditions is permitted to be both genocide and non-genocide during the Boolean reduction. Here rows with no more than two contradictory cases were coded as either genocides or non-genocides, while rows with more contradictory cases and rows without any empirical data were coded as 'don't cares'.

${ }^{42}$ Complex solutions focus on maximising consistency, and produce few but detailed combinations which are relatively specific to the presence of the outcome, but reduce the reach regarding coverage. Minimal solutions are the opposite extreme, producing many configurations in order to then have as many of the cases with the present outcome covered as possible, but in the process also covering many non-outcomes and thus reducing the consistency. Most commonly, an intermediate solution is thus used, which balances this and tries to find a solution which covers as many cases as possible, but still does not reduce the consistency too much.

${ }^{43}$ Consistency scores indicate how good a fit a particular combination is, that is how many non-occurrences of the outcome (here non-genocides) are also described by this term, thus falsely predicting an outcome where there is none. Coverage scores show how many of the outcome cases can be explained by this solution - raw scores detail how many cases are covered by this combination, while unique coverage means the cases which are explained only by this combination. To a certain degree, there is a trade-off between the consistency and coverage scores, as a solution with a higher consistency (thus explaining only the phenomenon itself and less 'other cases' too) will possibly not be able to explain the same amount of breadth as a very inclusive solution which explains all cases but also includes some nongenocides too. A consistency score of 1 , for instance, would indicate that there are no cases in which the outcome does not occur with these combinations of conditions, thus making these combinations truly sufficient for causing the outcome.
} 
a good result regarding consistency. Following from this, it means that 90 non-genocides were successfully predicted as such as they were not included in the configurations.

While this result does not provide absolute sufficiency, given the complexity of this topic, this is an extremely high score for consistency and is better than in many comparable studies. It also performs considerably better than Harff's model. ${ }^{44}$ While the amount of genocides correctly classified is comparable with Harff's value of $74 \%$, Harff's model incorrectly predicts $27 \%$ of nongenocides as false positives, while this model only predicts $9 \%$ of the non-genocides to be genocide. Altogether, this means that this QCA-produced model can discriminate better between genocides and non-genocides than Harff's model based on logistical regression

The configurations in this solution have certain elements in common, so that one can re-write them in the following way, which substantively is the same, but tells us more about how the terms are connected:

\section{$A^{*} S^{*}(I+P)+A^{*} I^{*} E^{*}\left(P^{*} \sim W+\sim P^{*} W\right)+S^{*} \sim I^{*} E^{*} P^{*} W$}

Substantively this means that genocide will occur, firstly, in autocracies (A) ${ }^{45}$ in which the ethnicity of the government members is salient (S) when an exclusionary ideology is present (I) or the country is in a state of major political upheaval $(\mathrm{P})$. The second set of configurations suggests that autocracies (A) with exclusionary ideologies (I) experience genocide when their economies are autarkic (E) and the county is either in a state of political upheaval $(\mathrm{P})$ but not at war $(\sim \mathrm{W})$, or reversely at war $(\mathrm{W})$ but not in a state of political upheaval $(\sim \mathrm{P})$. Lastly, a remainder of genocides can be predicted in countries in which the ethnicity of the elites is salient (S), but in which there is no exclusionary ideology $(\sim \mathrm{I})$ when the country's economy is autarkic $(E)$, the state is in political upheaval $(\mathrm{P})$ and at war $(\mathrm{W})$.

\section{Discussion of the underlying mechanisms}

The two primary configurations which are most interesting due to their large coverage are $A^{*} S^{*} I$ and $A^{*} S^{*} P$. This can be interpreted that the autocratic nature of the state provides a context which is primed for genocide, that is an opportunity structure allowing genocide to occur, while the salience of elite ethnicity can serve as a more proximate trigger, providing a motivation for elites, or at least as a categorisation along which lines of demarcation between the victim group and the rest of the population can be drawn. Finally, the ideology and the political upheaval serve as an additional motivation or opportunity structure, respectively. While Aand S are not sufficient alone, the addition of either this additional motivation I (within a slightly more constrained opportunity framework-just $\mathrm{A}$, not $\mathrm{A}^{*} \mathrm{P}$ ) or with less motivation (I not included) but within a stronger opportunity framework $\left(\mathrm{A}^{*} \mathrm{P}\right)$ allows genocide to occur. In the presence of an exclusionary ideology, the elites can want to enforce this through rigorous exclusionary policies, which can culminate in genocidal practices of elimination. On the other hand, in a context of high political upheaval, elites can feel threatened by challenging groups and then decide to target for elimination the group which is challenging them. They are able to do this as the political upheaval provides a framework in which a scapegoat can be identified and then use its elimination to consolidate their power and support in the population in the face of an imaginary threat. This is particularly interesting as it undermines the central importance of political upheaval as it has been posited not only in Harff's study, but also in much of the (comparative) case study literature. Political upheaval is one way to expand the political opportunity structure for elites in order that they can commit genocide if they have a sufficient motivation; however, it is not the only factor and it pales in significance with autocracy, for example, which is necessary in nearly all combinations leading to genocide occurrence. With enough motivation present in the form of an exclusionary ideology, the opportunity structure provided by political upheaval becomes irrelevant.

${ }^{44}$ Harff, "No Lessons Learned".

${ }^{45}$ Given that this is a necessary condition, it is clear that it should appear in every sufficient configuration, only being left out in some remainder configurations which try to include the two cases in which genocides did not occur in an autocratic context. 
Table 3: Solution case coverage and consistency by combinations.

\begin{tabular}{|c|c|c|c|}
\hline & Raw Coverage & Unique Coverage & Consistency \\
\hline $\mathbf{A}^{*} \mathbf{S}^{*} \mathbf{I}$ & 0.475 & 0.125 & 0.826 \\
\hline $\mathbf{A}^{*} \mathbf{S}^{*} \mathbf{P}$ & 0.500 & 0.125 & 0.741 \\
\hline $\mathbf{A}^{*} \mathbf{I}^{*} \mathbf{E}^{*} \mathbf{P}^{*} \sim \mathbf{W}$ & 0.075 & 0.025 & 1.000 \\
\hline $\mathbf{A}^{*} \mathbf{I}^{*} \mathbf{E}^{*} \sim \mathbf{P}^{*} \mathbf{W}$ & 0.075 & 0.050 & 1.000 \\
\hline $\mathbf{S}^{*} \mathbf{I}^{*} \mathbf{E}^{*} \mathbf{P}^{*} \mathbf{W}$ & 0.075 & 0.025 & 1.000 \\
\hline
\end{tabular}

Solution coverage: 0.750 .

Solution consistency: 0.769 .

The underlying mechanisms of these configurations can be best understood by highlighting the dynamics in individual cases ${ }^{46}$ The mechanisms of the configuration $\mathrm{A}^{*} \mathrm{~S}^{*} \mathrm{I}$ are well exemplified in the case of the genocide in Cambodia in the late 1970s: Pol Pot's clique of French-educated Khmer Rouge brothers took over power after a protracted armed struggle in 1975 and subsequently ruled through one of the most totalitarian regimes of the 20th century (A). This all-encompassing power of Ângkar, the Organisation, provided fertile turf for the regime to implement their extreme Communist ideology, which also fed on radical anti-Vietnamese rhetoric, underlining the importance of the leadership's Khmer identity (S); the vision that the Khmer Rouge had for Cambodia encompassed an extreme ideology which was geared at returning the country to an agrarian economy and glorifying the role of the peasant. In this context, the ideology was exclusionary (I) towards the urban population and intellectuals particularly, forcing all to evacuate the cities and become second-class citizens who had no rights at all; also they enforced racist (and thus exclusionary and eliminationist) policies towards the country's Vietnamese and Muslim Cham minority populations, as well as towards foreign nationals in the country.

Another example of this configuration, a case which is explained uniquely by $A^{*} S^{*} \mathrm{I}$, is provided by the Serbian genocide of ethnic Albanians in Kosovo between February 1998 and June 1999, which ended through NATO bombing and a ceasefire allowing NATO administration of Kosovo. Again, this occurred in the context of a more autocratic than democratic government under Slobodan Milosevic (A), whose Serbian identity was extremely important in politics (S), having cemented itself during the previous wars in the early 1990s with Slovenia, Croatia and in Bosnia, including the genocide which occurred there. This Serbian ethnic identity, as propagated by Milosevic and his nationalists, also incorporated a strong exclusionary ideology, as it is was purported that Serbia was for Serbians only and that the other nationalities within its borders should leave or be eliminated (I). Furthermore, Milosevic attempted to use this conflict, as he had the previous genocide in Bosnia, to frame security concerns along ethnic lines, and thus cement his hold on power and rally the population behind him.

Turning to the next configuration, Rwanda presents itself as an excellent example of $A^{*} S^{*} P$. The country under Juvénal Habyarimana did have multi-party parliament, but the system was nonetheless highly autocratic and dominated in all aspects of political life by Habyarimana's Mouvement républicain national pour la démocratie et le développement (MRND) party (A), which instigated and led the Hutu Power movement, proclaiming Hutu leadership as the only legitimate leadership for Rwanda (S) and branding the Tutsi minority as aliens in the country with increasingly few rights; the situation worsened after Habyarimana's airplane was shot down and he died, as

\footnotetext{
${ }^{46}$ Cases of genocide covered by A*S*I are: Afghanistan 1978-92, Algeria 1962, Angola 1975-94, Cambodia 1975-79, Ethiopia 1976-79, Guatemala 1978-90, Indonesia 1965-66, Iraq 1963-75, Iraq 1988-91, Myanmar (Burma) 1978, Rwanda 1963-64, Rwanda 1994, Somalia 1988-91, Sudan 1983-xx; as well as uniquely covered by this configuration: Burundi 1965-73, Equatorial Guinea 1969-79, Indonesia 1975-92, Syria 81-82, Yugoslavia 1998-xx. Cases of genocide covered by A*S*P are: Afghanistan 1978-92, Algeria 1962, Angola 1975-94, Cambodia 1975-79, Ethiopia 1976-79, Guatemala 1978-90, Indonesia 1965-66, Iraq 1963-75, Iraq 1988-91, Myanmar (Burma) 1978, Rwanda 1963-64, Rwanda 1994, Sudan 1983-xx, as well as uniquely covered by this configuration Angola 1998-xx, Bosnia 1992-95, Burundi 1993, DR Congo 1964-65, Nigeria 196770, Sudan 1956-72, Uganda 1980-86. [xx symbolises that the genocide ended after 1998 or is ongoing]
} 
hardliners took power and systematically assassinated all moderate political leaders $(\mathrm{P})$, thus paving the way for the genocide against the Tutsi minority.

A case explained uniquely by the combination $\mathrm{A}^{*} \mathrm{~S}^{*} \mathrm{P}$ is that of the genocide against Muslim Bosniaks by ethnic Serbs in Bosnia between 1992 and 1995. In the context of the break-up of the Yugoslav Federation in the early 1990s (P), war broke out between several of the republics, first between the central state which was dominated by Serbia and Slovenia, followed soon by Croatia, a conflict into which eventually Bosnia was also caught up. Both Croatia and Serbia had increasingly nationalistic leaderships (S) who mobilised along these ethnic lines of Serbian and Croatian in order to mobilise support and consolidate their grip on power (A). The political upheaval experienced in these countries gave the political leaders the opportunity to consolidate their power vis-à-vis their political opponents and to attempt to retain their positions in the course of these violent transitions. Particularly the ethnic Serbian military and paramilitary groups in Bosnia aimed at ethnically cleansing their territory and in this context engaged in genocidal action against the Bosniaks, expelling them from their homes and often killing the population.

As indicated in Table 3 the configurations $\mathrm{A}^{*} \mathrm{~S}^{*} \mathrm{I}+\mathrm{A}^{*} \mathrm{~S}^{*} \mathrm{P}$ cover by far the most cases within the dataset, explaining most of the cases of genocide and non-genocide, and were thus the focus of the further discussion here. However, the other three configurations all have perfect consistency, explaining an additional four unique cases not explained by the main two configurations, while not adding any extra non-genocides as false positives.

The configuration $S^{*} I^{*} E^{*} P^{*} W$ uniquely explains only the genocide in Pakistan from 1973 until 1977. In Pakistan there was a war against Balushi separatists (W) which was prompted by a rebellion backed by the National Awami Party against the economically autarkic (E) Pakistani central state $-\mathrm{a}$ form of political upheaval $(\mathrm{P})$ - which was motivated by the ethnic composition of the government (S), but not by any exclusionary ideologies propagated by them ( I). Primarily the specificity of this case is due to it being one of only two cases which occurred in countries which were not classed as autocracies.

The other two configurations which are less interesting by coverage, but have perfect consistency, thus being truly sufficient for genocide occurrence are $A^{*} I^{*} E^{*} P^{*} \sim W$ and $A^{*} I^{*} E^{*} \sim P^{*} W$, which can be summarised as $\mathrm{A}^{*} \mathrm{I}^{*} \mathrm{E}^{*}\left(\mathrm{P}^{*} \sim \mathrm{W}+\sim \mathrm{P}^{*} \mathrm{~W}\right)$. Given that they both lack the condition ethnic salience of the elite, it is plausible that these could be better at explaining politicides than the other discussed configurations, while at the same time still providing a distinct pathway into this form of mass violence; this cannot be conclusively resolved here as Harff's dataset does not differentiate between the two, but could be an interesting avenue for further research.

Both configurations include the necessary condition autocracy combined with an exclusionary ideology and the context of economic autarky. Here ideology presumably plays the part of the motivation for genocide as a strategy for dealing with a minority, while the autarkic economic system provides a facilitative condition under which this can occur, as the state does not have to fear that sanctions will damage its economy; one could frame this as the opportunity. However, the economic autarky is not sufficient in providing the opportunity for genocide (even in the absence of democratic controls in an autocratic country, but must be supplemented by either political upheaval in the context of peace (or at least the absence of war), or in the context of war without political upheaval. This suggests that political upheaval and war are not complimentary but interchangeable in the absence of the other. This can best be highlighted by two of the uniquely explained cases for the configurations $A^{*} I^{*} E^{*} \sim P^{*} W$ and $A^{*} I^{*} E^{*} P^{*} \sim W$, China in 1959 and China from 1966 to 1975 respectively. ${ }^{47}$ Both settings are relatively similar, given that it is the same country, with an autocratic regime, with an exclusionary ideology and in a context of economic autarky; here already the exclusionary ideology suffices as a motivation to commit genocide, and the autocratic regime and the autarkic nature of the economy provide an opportunity, but are not sufficient in and of themselves for genocide to occur, necessitating the inclusion of either political upheaval

\footnotetext{
${ }^{47}$ The other unique case explained by $\mathrm{A}^{*} \mathrm{I}^{*} \mathrm{E}^{*} \sim \mathrm{P}^{*} \mathrm{~W}$ is the Khomeini regime's actions in Iran from 1981 to 1992 , in which the autocratic and autarkic regime waged war against the Kurds and in this context enforced its exclusionary ideology of Islamic hegemony propagated as part of the Islamic revolution, violently targeting not only dissidents and rebel Kurds, but also Bahá'ís.
} 
or war as a further facilitating opportunity factor. In the genocide of 1959, in which people who were deemed as counterrevolutionary were targeted for elimination, including Tibetan Buddhists, landowners, and supporters of the former Chiang Kaishek regime; this occurred in the context of war against Tibet, providing an opportunity structure for the Communist leadership to define people they wanted to eliminate as state enemies. On the other hand, from 1966 to 1975, the genocide was truly a politicide targeting many groups within society for arrest, torture and execution, in order to further the aims of the Cultural Revolution. This, however, did not occur in the context of war, but instead was directly connected to the political upheaval of the Cultural Revolution, which provided not only the opportunity structure for committing such atrocities, but also the motivation to cleanse society in order to establish the new order envisaged by Mao Tse-tung.

\section{False Negatives and False Positives}

While the results of the QCA analysis identify several convincing pathways to genocide occurrence, these cannot explain all cases of genocide included in this study and the pathways sometimes falsely predict genocide, where actually a non-genocide occurs. False negatives are cases which experienced genocide, but their specific combination of conditions was not included in any of the solution configurations and thus genocide was not expected. For the false positives, the configurations predicted that genocide would occur, but the case is actually among the countries that did not experience genocide. Compared with Harff's statistical analysis, 48 the model classified a similar proportion of genocides correctly with around one quarter of cases being false negatives, but this model reduces the proportion of false positives, that is non-genocides predicted to be genocide, radically to $9 \%$ compared with Harff's $27 \%$.

False negatives misclassify genocides, with the solution configurations not expecting them to be genocides and thus reducing the coverage of the overall solution. ${ }^{49}$ Half of these were also genocides which Harff could not explain in her study, and Harff identifies weaknesses in the dataset as the key reason for this, something which is likely to also impact this study as it builds on the same data. ${ }^{50}$ The main problem is the political upheaval condition which takes the maximum value of political upheaval during the event; however, due to the cumulative nature of the condition, this is biased against short episodes. Argentina (1976-80) was coded as not in political upheaval due to the very low scores in the political instability data, however, given the dynamics of Peronist vs. military power struggles during this time, a qualitative assessment of the case would probably have coded this as political upheaval. The overthrow of the Allende administration by General Pinochet in Chile (1973-76), separatist aspirations of the Katanga province in Democratic Republic of Congo (1977-79), the violent separation of Bangladesh from Pakistan (1971), the turmoil surrounding Idi Amin's ascent to power in the Ugandan case (1971-79) could be equivalently argued. Similarly, Burundi (1988) was also coded as not in political upheaval, unlike the genocide in 1993; however, the power struggles between the Tutsi-dominated military and democratic reformers predated the 1993 genocide and could have allowed a qualitative assessment of Burundi being in political upheaval at this time. Furthermore, the Philippines (1972-76) was coded 0 on the category of salience of elite ethnicity, which captures the diversity of clans and ethnicity coalescing for power in Manila, but does not do justice to the fact that all of these were Christians, whereas the genocide victims were Muslim Moros from Mindanao, thus making the classification the probable reason for this misprediction as non-genocide. By using Harff's dataset an immediate comparability to her results is possible, but this also comes at the cost of some misclassifications in the data which she had already been forced to contend with.

Besides these genocides not covered by the solution, the two main configurations are also not strictly sufficient, as there also exist non-genocides in which these conditions are

\footnotetext{
${ }^{48}$ Harff, "No Lessons Learned".

${ }^{49}$ The genocides not accurately predicted by the model are: Argentina 1976-80, Burundi 1988, Chile 1973-76, DR Congo 1977-79, El Salvador 1980-89, Pakistan (now Bangladesh) 1971, Philippines 1972-76, Sri Lanka 1989-90, Uganda 1971-79, Vietnam (South) 1965-75.

${ }^{50}$ Chile 1973-76, El Salvador 1980-89, Philippines 1972-76, Sri Lanka 1989-90, Uganda 1971-79. See Harff, “No Lessons Learned ", 69.
} 
present, so-called false positives. ${ }^{51}$ One possible explanation for some of these cases is the fact that they are very similar to other cases which were actually genocide, as they are temporally proximate and occur in the same country, thus sharing some of the same structural conditions. This is the case for nearly half of the false positives: Algeria (1991-xx), Cambodia (1997), DR Congo (1992-xx) and Pakistan (1983-xx). In future research, a more differentiated focus would be possible if one can overcome the dichotomy of conditions, meaning that more structural conditions would be able to vary more subtly over time. Furthermore, some cases' false prediction of being a genocide could also, as with the false negatives, be due to coding problems: Both Turkey (1971) and Romania (1989) were coded as having an exclusionary ideology in Harff's dataset, a categorisation which could be contested.

\section{Conclusion and Outlook}

The aim of this paper was to look into the research question of why genocides occur and what combinations of conditions play together to determine its occurrence, and further this research agenda by applying a different methodology to previous studies: the set-theoretic QCA. The key advantage provided by QCA is that it allows for complexity and explicitly models into its analysis the complexity of the world, while also showing up generalisable patterns. The analysis of genocide using QCA provides multiple combinations of conditions which are sufficient for causing genocide to occur, thus allowing for several pathways to be described and each of these to present a relatively complex picture; thus, it does not present results as parsimonious as statistical analyses, but radically reduces the complexity of why genocide occurs in each individual instance to observable patterns. Using the conjunctural and combinatorial logic of QCA, this paper examined 139 cases of genocide and non-genocide from the Political Instability Task Force's (PITF) State Failure Problem Set in direct comparison to Barbara Harff's seminal statistical study on genocide occurrence. This paper presented more systematic results than past research regarding sufficient and necessary conditions. The analysis revealed that the presence of an authoritarian regime is necessary for genocide to occur. Furthermore, autocratic regimes with governments whose elites' ethnicity is salient will experience genocide in the presence of either an exclusionary ideology or high political upheaval; also, the same outcome will occur if an economically autarkic autocracy propagates an exclusionary ideology in the context of either high political upheaval, not in war, or in war without high political upheaval.

Furthermore, this analysis brings more depth into the discussion of the different conditions which coalesce to make genocide occur, demonstrating not just the impact of individual conditions as most statistical work does, but instead showing how the conditions combine to certain configurations which are sufficient for genocide. By pursuing this methodology, it is possible to take previous findings of what are important determinants of genocide and structure them into meaningful combinations.

The fact that the presence of autocratic regimes is necessary for genocide to occur is perhaps not surprising due to the dichotomous nature of this condition, but is certainly an interesting finding of this paper. Furthermore, it is interesting to note that while political upheaval can play a part in causing genocide, its role is much more understated than is suggested in previous literature, including in Harff's analysis. Political upheaval is necessary in the provision of an augmented opportunity structure in the context of autocratic regimes with ethnically salient governments, with the former providing a baseline of opportunity and the latter a fundamental genocidal motivation; however, political upheaval became irrelevant when an exclusionary ideology was present, as this provided an overarching motivation which can be realised even within the context of a minimal autocratic opportunity structure. Also, in other configurations political upheaval is not as central as previously asserted, as the solution demonstrated that it is functionally equivalent to the occurrence of war, both providing an opportunity structure in addition to the autocratic regime.

This paper presents a new perspective on why genocides occur and opens up new avenues for future research: First, this paper has had to work with crisp set QCA using only dichotomous

${ }^{51}$ The non-genocides which are also covered by these configurations are Cambodia 1997, Chad 1965-94, Congo-Kinshasa 1992-xx, Liberia 1985-xx, Sierra Leone 1991-xx, Turkey 1971, Romania 1989, Algeria 1991-xx, Pakistan 1983-xx. 
conditions. If it were possible to find an ordinal scale for genocide or a way of identifying cases as partly genocidal, then one could run more rigorous fuzzy setQCA tests, allowing for continuous coding of all conditions without reducing the complexity of the available data to a simple $0 / 1$ dichotomy. Second, the country-level is probably not the most appropriate for the study of genocide, as some genocides occur within specific regions of a country, while others are perpetrated by one government but across borders into other countries. It would be a worthwhile endeavour to conduct a study which took these different spatial issues into account. Finally, as suggested in the discussion section, it could be interesting in a future study to differentiate between different types of genocide to gauge different pathways-the differentiation between politicide and genocide could be one avenue, but further work on typologising genocide could also bring to light helpful nuances. This could possibly strengthen the results and allow for a clearer set of conditions to crystallise for each distinct phenomenon.

Given that genocides vary greatly in their implementation and thus reality is extremely complex, the reduction of the dynamics across 139 cases to these combinations is certainly a success, demonstrating some more generalisable dynamics across cases. While this paper was not able to provide such clear-cut and parsimonious results as previous statistical analyses, it is able to provide new insights into genocide occurrence due to QCA's unique combinatorial and conjunctural approach. With these results and with further developments of the dataset and its analysis, policy makers and civil society actors should be better armed to take the identified configurations and flag situations which are particularly at risk of genocide occurring. The complex nature of the several pathways and each of their configurations allows these actors to better understand which dynamics occur under which circumstances and how the same condition can have varying effects in different contexts. Altogether, this complex-orientated approach will allow more tailored responses to at-risk situations to be developed and possibly play a contribution to ridding the world of the scourge of genocide.

\section{Acknowledgements}

I would like to thank Paul Steinheuer, Alice Williams, Judith von Heusinger, Sergio Gemperle, Dominic Pfeiffer, Lisa Gutenbrunner and Kerstin Hamman for comments on early drafts of this work.

\section{Bibliography}

Bara, Corinne. 2014. "Incentives and opportunities: A Complexity-oriented Explanation of Violent Ethnic Conflict." Journal of Peace Research Vol. 51, No. 6: pages 696-710. http://dx.doi. org $/ 10.1177 / 0022343314534458$

Center for Systemic Peace, Polity IV Annual Time-Series 1800-2011, Polity IV Project, Political Regime Characteristics and Transitions, 1800-2011, 2011. Data available from: http://www. systemicpeace.org/inscr/inscr.htm. (accessed 15 May 2013).

Chalk, Frank and Kurt Jonassohn. 1990. The History and Sociology of Genocide: Analyses and Case Studies. New Haven: Yale University Press.

Colaresi, Michael and Sabine C. Carey. 2008. "To Kill or to Protect: Security Forces, Domestic Institutions, and Genocide." Journal of Conflict Resolution Vol. 52, No. 1: pages 39-67. http://dx.doi.org/10.1177/0022002707310427

Esteban, Joan, Massimo Morelli, and Dominic Rohner. Forthcoming. "Strategic Mass Killings." Journal of Political Economy.

Gleditsch, Nils Petter, Peter Wallensteen, Mikael Eriksson, Margareta Sollenberg, and Håvard Strand. 2002. "Armed Conflict 1946-2001: A New Dataset." Journal of Peace Research Vol. 39, No. 5: pages 615-637. http://dx.doi.org/10.1177/0022343302039005007

Goldsmith, Benjamin E., Charles R. Butcher, Dimitri Semenovich, and Arcot Sowmya. 2014. "Forecasting the Onset of Genocide and Politicide. Annual out-of-sample forecasts on a global dataset, 1988-2003." Journal of Peace Research Vol. 50, No. 4: pages 437-452. http://dx.doi.org/10.1177/0022343313484167

Fein, Helen. 1990. “Genocide: A Sociological Perspective." Current Sociology Vol. 38, No. 1: pages 32-91, 39. 
Freedom House. 2013. "Country ratings and status, FIW 1973-2013." Washington, DC: Freedom House. Available from: http://www.freedomhouse.org/report-types/freedom-world. (accessed 15 May 2013).

Freeman, Michael. 1991. "The Theory and Prevention of Genocide." Holocaust and Genocide Studies Vol. 6, No. 2: pages 185-199. http://dx.doi.org/10.1093/hgs/6.2.185

Harff, Barbara. 2003. "No Lessons Learned from the Holocaust? Assessing Risks of Genocide and Political Mass Murder since 1955." American Political Science Review Vol. 97, No. 1: pages 57-73. http://dx.doi.org/10.1017/S0003055403000522

Harff, Barbara. “Genocide and Politicide Model Data (Phase III: 1955-1999)." Available from: http:// www.gpanet.org/webfm send/51. (accessed 11 January 2013).

Harff, Barbara. "Annual Data on Cases of Genocides and Politicides 1955-2006.xls." Available from: http://www.gpanet.org/content/genocides-and-politicides-events-1955-2002. (accessed 12 November 2012).

Krain, Matthew. 1997. "State-Sponsored Mass Murder: The Onset and Severity of Genocides and Politicides." The Journal of Conflict Resolution Vol. 41, No. 3: pages 331-360. http://dx.doi. org/10.1177/0022002797041003001

Kuper, Leo. 1981. Genocide. Its Political Use in the Twentieth Century. New Haven: Yale University Press.

Mann, Michael. 2005. The Dark Side of Democracy: Explaining Ethnic Cleansing. Cambridge: Cambridge University Press.

Marshall, Monty G. Keith, Jaggers, and Ted Robert Gurr. 2011. “Dataset Users' Manual. Polity IV Project." Vienna, VA: Center for Systemic Peace. Available from: http://www.systemicpeace. org/inscr/p4manualv2010.pdf. (accessed 01 March 2013), pages 15ff.

Melson, Robert. 1992. Revolution and Genocide. On the Origins of the Armenian Genocide and the Holocaust. Chicago: University of Chicago Press.

Montalvo, Jose G. and Marta Reynal-Querol. 2008. "Discrete Polarisation with an Application to the Determinants of Genocides." The Economic Journal Vol. 118, No. 9: pages 1835-1865. http://dx.doi.org/10.1111/j.1468-0297.2008.02193.x

Moses, A. Dirk. 2002. "Conceptual Blockages and Definitional Dilemmas in the 'Racial Century': Genocides of Indigenous Peoples and the Holocaust." Patterns of Prejudice Vol. 36, No. 4: pages 7-36. http://dx.doi.org/10.1080/003132202128811538

Powell, Christopher. 2007. "What Do Genocides Kill? A Relational Conception of Genocide." Journal of Genocide Research Vol. 9, No. 4: pages 527-547. http://dx.doi. org $/ 10.1080 / 14623520701643285$

Ragin, Charles. 2008. Redesigning Social Inquiry. Fuzzy Sets and Beyond. Chicago: University of Chicago Press. http://dx.doi.org/10.7208/chicago/9780226702797.001.0001

Ragin, Charles. 1987. The Comparative Method. Berkeley: University of California Press.

Rost, Nicolas. 2013. "Will It Happen Again? On the Possibility of Forecasting the Risk of Genocide." Journal of Genocide Research Vol. 15, No. 1: pages 41-67. http://dx.doi.org/10.1080/14623528 $\underline{.2012 .759398}$

Rummel, Rudolph. 1994. Death By Government. New Brunswick: Transaction Publishers.

Ulfelder, Jay and Benjamin Valentino. 2008. "Assessing Risks of State-Sponsored Mass Killing." Working Paper.

Uppsala Conflict Data Program-Peace Research Institute Oslo. 2012. “UCDP/PRIO Armed Conflict Dataset v.4-2012, 1946 - 2011." Oslo: Peace Research Institute Oslo. Available from: http://www.pcr.uu.se/research/ucdp/datasets/ucdp prio armed conflict dataset. (accessed 15 May 2013).

Valentino, Benjamin, Paul Huth, and Dylan Balch-Lindsay. 2004. "'Draining the Sea': Mass Killing and Guerrilla Warfare." International Organization Vol. 58, No. 2: pages 375-407. http://dx.doi.org/10.1017/S0020818304582061

Weitz, Eric D. 2003. "The Modernity of Genocides; War, Race, and Revolution in the Twentieth Century." in The Specter of Genocide: Mass Murder in Historical Perspective. Edited by Robert Gellately and Ben Kiernan, pages 53-74. Cambridge: Cambridge University Press. 